\title{
In vitro における歯髄の生長に伴なう細胞形態と
}

\section{コラーゲンタイプ組成の変化}

\author{
五 藤 陽 三 島田二 郎 斉藤 滋 \\ 神奈川歯科大学 口腔生化学教室*
}

〔受付 : 昭和55年 3 月19日]

\begin{abstract}
抄録: 三つの生育段階の歯牙組織から歯剈を採取し，トリプシンとコラゲナーゼにより遊離細胞を集め, 各 stage の細胞が産生したプロコラーゲンおよびそれらの培養細胞の形態を比較検討した。その結果，各 stage の歯喵組織はすべてタイプI とタイプIIIの 2 種類のプロコラーゲンを合成していた。しかしながら， 歯髄組織が成育するに伴ないタイプI とタイプ孟のプロコラーゲンの 合成された割合は変化し，後者が優位 を占めていくことが明らかとなった。それと同時に培養細胞の形態も明らかに変化していくことが見出され た。
\end{abstract}

\section{緒言}

歯骾は象牙質の形成と維持に関与しており周囲 を石灰化した象牙質に囲まれた極めて特異な組織 である。コラーゲンは結合組織に存在する主要な 蛋白質であるが，歯髄には他の結合組織と比較し て，コラーゲンは比較的少量しか含まれていな (1)。著者らは家鬼切歯歯骾は 2 種類のタイプの コラーゲン（タイプI およびタイプIII）を合成し ていることを見出した ${ }^{2)}$ 。Schutleworth らは歯乳 頭と歯髄の 2 つの組織のコラーゲンを比較し， 2 種類のタイプのコラーグンの含有量に 差異のある ことを報告している゙๋。コラーゲンはプロコラー ゲンという前駆体の形で合成された後，細胞自身 の作った酵素により $\mathrm{N}$ 端側， C 端側の余分のペプ チドが除去されコラーゲンとなり始めて線維の形 成が行なわれる。この過程の解析には細胞培養法 は極めて貢献して来ている4”。著者らは培養歯髄 細胞は 2 種類のプロコラーダン（タイプ I プロコ ラーゲンを主成分として，他にタイプIIIプロコラ ーゲン）を産生していることを見出した ${ }^{5)}$ 。本研
究では，歯髅の生長に伴ない， in vitro において 3 つの歯髄の生育時期の細胞がどのようなコラー ゲンを産生しているかを調べたところ，産生され たコラーゲンのタイプ組成に差異の存在すること のみならず，培養細胞の形態にも違いのあること を見出したので報告する。

\section{実験方法}

牛の前歯歯髄から次の様な 3 種類のステージを 集めた。（I）歯冠部が形成途中にある歯牙，(II） 歯根部が約 $1 / 4$ 完成した歯牙，(III）萌出している が末咬合歯牙。それぞれのステージの歯髄組織を 採取し, $100 \mu \mathrm{g} / \mathrm{ml}$ のカナマイシンと $2.0 \mu \mathrm{g} / \mathrm{ml}$ の ファンギゾンを含むリン酸一生食水 (PBS) で十分 に洗浄した。歯髄組織をスライスし, $\mathrm{Ca}^{+}$と $\mathrm{Mg}^{+}$ を含まない PBS 中に移し， $0.25 \%$ トリプシンと $0.02 \%$ 細菌由来コラゲナーゼで処理した ${ }^{2,5)}$ 。 酵 素処理により遊離した細胞は Dulbecco-Vogt $\mathrm{MEM}$ 培地（上記 2 種の抗生物質と $10 \%$ 牛胎児血 清を含む）に移し，単層培養された ${ }^{5,6)}$ 。ラベリ ングは $2 \mu \mathrm{Ci} / \mathrm{ml}$ の [5- $\left.{ }^{3} \mathrm{H}\right]$ プロリン (NEM, 比

Changes in cell marphology and collagen types during the development of the dental pulp cells in vitro

Yozo Gotoh, Jiro Shimada and Shigeru Saito (Kanagawa Dental College, Department of Oral biochemistry, Yokosuka)

* 横須賀市稲岡町 82 ( Jap. J. oral Biol., 22 : 388-391, 1980. 
活性 $23 \mathrm{Ci} / \mathrm{m}$ mole), $\beta$-aminopropionitril $(50 \mu \mathrm{g} /$ $\mathrm{ml})$ および L-ascorbic acid $(50 \mu \mathrm{g} / \mathrm{ml})$ を培養液 の中にそれぞれの濃度に添加することにより行な われた ${ }^{2,6)}$ 。24時間後, 培養液を集め, プロテア ーゼインヒビター（最終濃度, $25 \mathrm{mM}$ EDTA, 10 mM N-ethylmaleimide および, $300 \mu \mathrm{M}$ phenylmethylsulfonylfluoride) を添加し, 遠沈後, 培養 液中のプロコラーゲンは前に述べた様な方法で精 製した ${ }^{5,8)}$ 。塩析後の沈測物を遠心により集め, 2 $\mathrm{M}$ 尿素および0.1\% Triton X-100を含む $50 \mathrm{mM}$ Tris- $\mathrm{HCl}(\mathrm{pH} \mathrm{7.5)}$ に可溶化した後, 上記の緩衝 液に対して透析した。プロコラーゲンの 分離は DEAE-cellulose カラムクロマトグラフィーによ り既に述べたような方法で分離した ${ }^{5,7) 。 コ ラ ー ~}$ ゲン鎖を分離するためには, 硫安塩析による沈澱 の一部を $0.5 \mathrm{M}$ 酢酸に可溶化し, $100 \mu \mathrm{g} / \mathrm{ml}$ のペプ シンで $4^{\circ} \mathrm{C} 24 \sim 72$ 時間処理した後，前に報告した 方法により CM-cellulose にかけカラムクロマト グラフィーを行なった ${ }^{2,6)}$ 。

ラベルコラーゲンのブロムシアン分解は既に述 べたような方法により行った ${ }^{15)}$ 。

液体クロマトグラフィーに用いたキャリヤーの タイプ I， III ラーゲンは前に述べたような方法 により調製した ${ }^{2,5,7) 。 ~}$

放射活性は Aloka LSC-653を用いて計測し $た^{2,5,6)}$ 。

\section{結果}

3 種の歯髄の生育ステージの細胞が 合成したコ ラーゲン鎖の CM-cellulose クロマトグラフィー による溶出位置はキャリャーのタイプI コラーダ ン， タイプIIIコラーゲンとそれらのブロムシアン 分解物の CM-cellulose カラムクロマトグラフィ 一による溶出位置により同定された（図示せず）。 各鎖の分離は良好で十分に定量分析出来る結果で あった。それぞれの生育ステージの細胞は 2 種類 のコラーゲン（タイプI コラーゲンの $\alpha 1 ， \alpha 2$ 鎖 とタイプIII ラーゲン $[\alpha 1 \text { (III) }]_{3}$ を合成している ことが判明した(図 1)。しかしながら，タイプI コラーゲンとタイプIII ラーゲンとの占める面積 の割合は，明らかに歯髄の生育ステージと共に変 化していくことを認めた。ステージ I ではタイプ

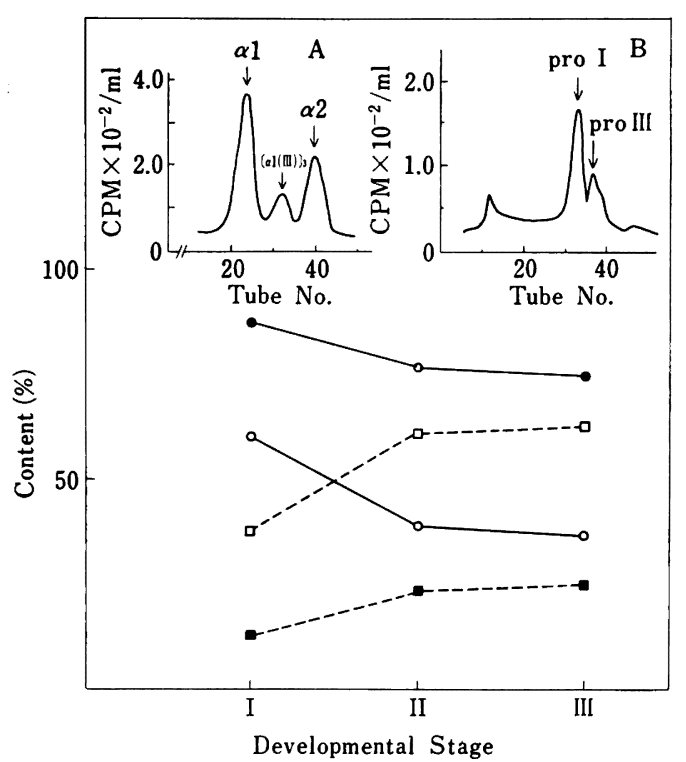

図 1 歯鹃の生育に伴なうコラーゲンタイプ組 成の変化

CM-cellulose (O，ロ)および DEAE-cellulose $(\bigcirc, \square)$ を用い定量された培養液中のタイプ I $(-)$, タイプIII $(\cdots)$ コラーゲン

(A) Stage I の細胞の 合成したプロコラーゲ ンをペプシン消化後の CM-cellulose クロマト グラフィー, (B) Stage I の細胞の合成したプ ロコラーゲンの DEAE-cellulose クロマトグ ラフィー

III コーゲンは $12 \%$ であるが， ステージIIではそ れぞれ $23 \% ， 24 \%$ とタイプIII コラーゲンの占める 割合が増加していることが明らかとなった。特に ステージIとIIの間におけるコラーゲンのタイプ 組成の変化は顕著であった。

一方, DEAE-cellulose クロマトグラフィーに より分離された 2 種のタイプのプロコラーゲンは それぞれの分画を回収し，ペプシン消化後ブロム シアン分解し，CM-cellulose にかけブロムシアン ペプチドを分離して同定した(図示せず)。合成さ れたプロコラーゲン量から見てもタイプI プロコ ラーゲンは 歯髄の生育に 伴なって 減少傾向にあ り，タイプIIIプコラーゲンは逆に増加していく ことが明らかとなった(図 1 )。

培養歯髄細胞の細胞形態は，ステージ I ではい わゆる satellite-like であった(図 2)。ステージII では spindle-like であった。しかしながら，ステ ージII とIIIにおいて，光顕レベルでは細胞の形態 


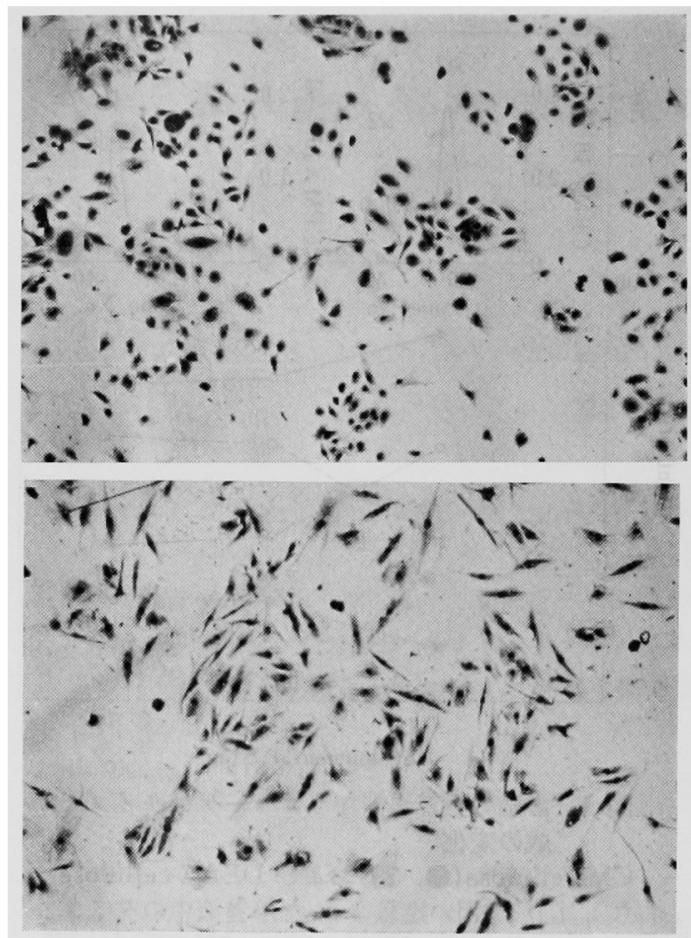

図 2 培養歯髄細胞の Jacobson 染色

（上） stage I の細胞 $(\times 125)$

(下) stage II 細胞 $(\times 130)$

には差異を認めることが出来なかった。これ迄に 述べた結果は，す心゙て初代培養の細胞についての 成果であるが， 3 代継代後の細胞においても培養 細胞の細胞形態は光顕的には初代の細胞のそれと それぞれ差異を認めることが出来なかった。

\section{考察}

この実験で得たコラーゲンのタイプ組成が $2 つ$ の定量法 (DEAE-cellulose カラムクロマトグラ フィーによるプロコラーゲンの分離定量, 細胞の 合成したすべてのコラーゲン性物質をペプシン消 化し, CM-cellulose カラムクロマトグラフィーに よりタイプ I，IIIコラーゲンを分離定量）により大 きな差異の存在することを認めた。その原因とし てプロコラーグンからコラーゲンへの processing がプロコラーゲンのタイプにより異なることが挙 げられる10)。しかしながらプロコラーゲンの processing はこの実験条件 (10\%血清濃度) では遅い ことが知られている ${ }^{7,9)}$ 。又コラーゲンのタイプ組 成を決定するにはプロコラーゲンを分離し，定量
することが最も信頼性に富むと言われている7,91。 従ってペプシン消化法において，2つのコラーゲ ンの回収に差異のあることが原因かも知れない。 しかしながら，現在ここで得た 2 種の方法による コラーダンのタイプ組成の差異の原因を明らかに することは出来ない。我々はプロコラーゲンの分 離定量により得られたタイプ組成がより信憑性に 富むものと考えている。

歯冠部完成前後の 細胞が産生したプロコラーゲ ンのタイプ組成についてみると，38\%から $62 \%$ と 大きくタイプIIIプコラーゲンが増加しているこ とが明らかである。コラーダンのタイプは現在の ところ少なくとも 4 種類 (タイプ I からIV) 存在 すると言われている4)。そしてそれらの組織にお ける役割についてはさまざまな議論がなされてい る11)が，未だに明らかとはされていない。しかし ながら，一般にタイプIIIコラーゲンは幼若な組織 に多いと言われており，10週より80歳までの人皮 膚のコラーゲンをみるとタイプI コラーゲンが直 線的増加にあることが報告されている12)。歯髄は， 成長のある一時期にタイプIIIコラーゲン含量が増 大していることは興味ある現象である。歯髄の生 育に伴ないプロリル水酸化酵素活性の変化をみる と，歯冠部形成時に高いと報告されている ${ }^{13)}$ 。従 っておそらくこの時期はタイプIIIコラーダンの合 成がより盛んとなっているものと思われる。しか し，コラーゲンの崩壊過程を考虑すると，コラー ゲンのタイプによってその崩壊速度が異なる結 果, 見掛け上分析するとコラーゲンのタイプ組成 に変化が生じるという可能性がある。これらの問 題は今後の成果に待たねば解決出来ないであろ う。

歯髄は歯乳頭から生育に伴なって血管系の豊富 な組織に移行すると言われる。タイプIIIララーゲ ンは血管系に比較的多量存在する ${ }^{14)}$ ので，ステー ジの増加に伴ってここで得たコラーゲンのタイプ 組成の変化を反映しているのかも知れない。しか しながら, 我々の細胞培養では血管由来の細胞 は混入していないものと思われる。又培養細胞の 形態が歯髄の生育に伴なって変化していることを 考慮すると, 細胞自体の変化が起きているとも考 えられる。これが in vitro で生じているのか in 
vitroにおいた時に始めて現われるものか明らか ではない。

最近, 我々は歯髄細胞を長時間培養するとタイ プI トリマーコラーゲン $[\alpha 1(\mathrm{I})]_{3}$ の合成がある ことを認めだ”。タイプIトリマーュラーゲンは 胚性組織に多いと言われている(16)ことから歯髄組
織は未分化な細胞の多い組織であると考えられ る。このような細胞集団から成る歯髄組織は，外 界からの象牙質を介しての種々の刺激に対して積 極的に反応し，第 2 象牙質形成や歯髄結石の形成 といった硬組織形成に関与しているものと考えら れる。

Summary : Procollagen synthesized by bovine pulp cells was studied in the development of tissue in vitro. All the pulp cells in the development stage produced type I and type III procollagens. During tissue development the ratio of type I : type III procllagen changed with type III becoming predominant form. Morphological observation of pulp cells showed alteration of cell morphology during tissue development in vitro. These results suggested the presence of the relation between the synthesized collagen types and cell morphology.

\section{文献}

1) ORLowski, W. A.: Analysis of collagen and mucopolysaccharides and glycoporteins in bovine and porcine pulp. Arch. Oral. Biol. 19 : 255-258, 1974.

2) 五藤陽三, 斎藤 滋：培養歯髄細胞による夕イ プ I トリマーコラーゲン $[\alpha 1(\mathrm{III})]_{3}$ の産生, 歯 科基礎誌， $20: 643-649,1978$.

3) Schuttleworth, C. A., Ward, J. L. and Hirschman, P. N.: The presence of type III collagen in the developing tooth. Biochim. Biophys. Acta 535 : 348-355, 1978.

4）五藤陽三：歯科領域における組織培羕 I, 組織 培養におけるコラーゲンの合成と 分組織培養, 解, $3: 21-30,1977$.

5) Gotoh, Y. Saito, S. and SATo, A. : Synthesis of procollagen by dental pulp cells from incisor in vitro. J. Biochemistry 86 : 1037-1040, 1979.

6）五藤陽三，斎藤 滋 : 培養七卜歯根膜細胞によ るプロコラーダンの合成，歯科基礎誌，20： 825-831, 1978.

7) Gotoh, Y. and SAIto, S., and SATo, A. : Synthesis of procollagen by odontogenic cells of rabbit tooth germ. Biochim. Biophys. Acta 587 : 253-262, 1979.

8) Lichtenstein, J. R., Beyer, P.H., Smith, B. D. and MARTIN, G. R.: Identification of the collagenous proteins synthesized by cultured cells from human skin. Biochemistry 14 : 1589-1594, 1975.

9) Burke, J. M., Bailian, G., Ross, R. and Bornstein, P.: Synthesis of types I and
III procollagen and collagen by monkey aortic smooth muscle cells in vitro. Biochemistry 16 : 3243-3249, 1977.

10) GoldBerG, B.: Kinetics of processing of type I and III procollagens in fibroblast culture, Proc. Natl. Acad. Sci. USA 74: 3322-3325, 1977.

11) Miller, E. J. and Martukas, V. J. : Biosynthesis of collagen. Fed. Proc. 33 : 1197-1204, 1974.

12) Epstein, E. H. Jr. : $[\alpha 1 \text { (III) }]_{3}$ Human skin collagen, release by pepsin digestion and preponderance in fetal life. J. Biol. Chem. 249 : 3225-3231, 1974.

13) Hayakawa, T., Numata, Y. and Iizima, K. : Changes in prolylhydroxylase activity during the development of the bovine dental pulp. Arch. Oral Biol. 23 : 831-833,

14) BARnes, M. J., MORTON, L. F. and LEVENE, C. I.: Synthesis of collagens type I and III by pig medial smooth muscle cells in culture. Biochim. Biophys. Res. Commun. $70: 339-347,1976$.

15) Ohta, Y. Gotoh-Hibino, Y., Asaba, K., SugiurA, $K$. and SAMEJima, T.: On the conformation changes of hen-egg white lysozyme by chemical scission. Biochim. Biophys. Acta, $236:$ 802-805, 1971.

16) Jimnes, S. A., BASheY, R. I., Benditt, M. and YANOWSKI, R.: Identification of collagen $\alpha 1$ (I) trimer in embryonic chick tendon and calvaria. Biophys. Biochem. Res. Commun. 78 : 1354-1361, 1977. 